\title{
Upaya Meningkatkan Kompetensi Guru Kelas Dalam Penyusunan Rencana Pelaksanaan Pembelajaran Harian (RPPH) Guru TK PGRI 4 Mataram Semester Satu Tahun pelajaran 2018/2019 Melalui Pendampingan
}

\author{
Sri Handayani \\ Kepala TK PGRI 4 Mataram.
}

\begin{abstract}
Abstrak. Latar belakang diadakannya Penelitian ini adalah rendahnya kompetensi guru sasaran Di TK PGRI 4 Mataram dalam penyusunan Rencana Pelaksanaan Pembelajaran Harian (RPPH) yang berdampak kurang percaya diri dalam proses pembelajaran. Solusinya diadakan pendampingan baik secara kelompok maupun individu dalam penyusunan RPPH. Tujuannya adalah untuk mengetahui efektifitas pelaksanaan pendampingan berbasis KKG dalam upaya meningkatkan kompetensi guru dalam menyusun RPPH, yang bermanfaat untuk meningkatkan profesionalisme sebagai kepala sekolah dan bagi guru untuk meningkatkan proses pembelajaran di kelas. Hipotesis tindakan: meningkatkan kompetensi guru sasaran TK PGRI 4 Mataram semester satu tahun pelajaran 2018/2019 dalam menyusun RPPH. Penelitian ini dilaksanakan sebanyak dua siklus, masing-masing siklus dua kali pertemuan. Tahapan setiap siklus adalah perencanaan, pelaksanaan, pengamatan, dan refleksi. Indikator keberhasilan dalam penelitian ini adalah; 1) hasil observasi Kepala Sekolah maupun observasi guru selama proses pendampingan telah memperoleh skor rata-rata $\geq 4,0,2$ ) hasil kerja guru dalam penyusunan $\mathrm{RPPH}$ mencapai $\geq 85 \%$ dengan nilai rata-rata $\geq 80,00$. Hasil penelitian pada siklus I observasi Kepala Sekolah rata-rata $(3,20)$, observasi guru rata-rata $(3,50)$ dan hasil kerja individual rata-rata nilai $(70,987)$ dengan prosentase ketercapaian $(0 \%)$. Pada siklus II observasi Kepala Sekolah rata-rata $(4,50)$, observasi guru rata-rata $(4,50)$ dan hasil kerja individual rata-rata nilai $(89,82)$ dengan prosentase ketercapaian (100\%). Indikator keberhasilan telah tercapai, penelitian di nyatakan berhasil dan dihentikan pada siklus II. Kesimpulan; pelaksanaan pendampingan dapat meningkatkan kompetensi guru sasaran TK PGRI 4 Mataram dalam penyusunan RPPH. Disarankan agar Kepala TK lainnya melakukan penelitian sejenis dalam upaya peningkatan kompetensi guru, dan kepada guru mata pelajaran agar mampu menyusun RPPH.
\end{abstract}

Kata Kunci : Pendampingan $-R P P H$

\section{PENDAHULUAN}

Latar belakang

Sikap bijak kepala Taman Kanak-Kanak

(TK) dalam menyikapi persoalan yang berkembang dan membuka peluang dialog bagi setiap guru, tentu akan memberi ketenangan dan kenyamanan kerja. Kondisi ini dapat mendorong aktivitas dan produktivitas kerja guru dalam menyusun Rencana Pelaksanaan Pembelajaran Harian (RPPH). Upaya menjadikan Taman Kanak-kanak (TK) sebagai lingkungan kondusif bagi anak, menuntut kesiapan guru untuk menyusun RPPH yang proaktif terhadap perkembangan psikologis dan karakter anak usia TK. Upaya positif guru TK untuk membelajarkan anak-anak usia TK hendaknya penuh dengan ramah tamah, murah senyum, cerah ceria, dan selalu bergembira dan penuh dengan kasih sayang. Kondisi yang demikian akan membawa suasana kelas menjadi hidup, ramai dalam arti proses pembelajaran kondusif. Untuk mewujudkan hal ini guru TK harus mampu menyusun Rencana Pelaksanaan Pembelajaran Harian (RPPH) yang merujuk pada proses pembelajaran yang senantiasa riang ria penuh dengan kegembiraan tetapi tetap kondusif.

Kondisi yang terjadi di TK PGRI 4 Mataram pada semester dua tahun pelajaran 2018/2019 khususnya kompetensi dalam 
penyusunan RPPH dapat dijelaskan sebagai berikut:

\begin{tabular}{|c|l|c|c|}
\hline No & \multicolumn{1}{|c|}{ Nama Guru } & Guru Kelas & Kondisi RPPH \\
\hline 1. & Hj. Ropaah, S.Pd & A & Konvensional \\
\hline 2. & Tutik Suryani, A.Md & B & Downloaad di Intemet \\
\hline 3. & Jurianti, S.Pd & A & Adopsi dari gunu TK lain \\
\hline 4. & Lale Dini Sukriani, A.Ma & B & Belum menyusun RPPH \\
\hline
\end{tabular}

Rendahnya kompetensi guru TK dalam penyusunan RPPH disebabkan oleh beberapa faktor: 1) kurangnya perhatian Kepala TK PGRI 4 Mataram dalam melakukan pendampingan terhadap guru binaannya dalam penyusunan RPPH, 2) kebanyakan guru TK di TK PGRI 4 Mataram belum mengikuti pendidikan dan pelatihan (diklat) khususnya dalam penyusunan RPPH, 3) kegiatan kelompok kerja guru (KKG) di TK PGRI 4 Mataram tidak berjalan, dan 4) guru menyusun RPPH sendiri-sendiri dan menurut pemahaman dan tingkat pemahaman sendiri.

Banyak solusi yang bisa dilakukan oleh kepala TK PGRI 4 Mataram, diantaranya adalah dengan melaksanakan pendampingan bagi guru dalam penyusunan RPPH dengan harapan RPPH yang telah tersusun dapat dilaksanakan dalam proses pembelajaran di kelas/diluar kelas sesuai dengan schedule/skenario yang telah direncanakan pada RPPH. Dari beberapa alternatif solusi yang dilakukan oleh peneliti yaitu dengan pendampingan. Pendampingan dimaksud dilakukan secara klasikal dan secara individual.

Ada beberapa keunggulan pembimbingan guru dalam penyusunan RPPH dengan pendampingan klasikal maupun pendampingan individual yaitu; 1) dapat memecahkan permasalahan guru terutama dalam penyusunan $\mathrm{RPPH}, 2$ ) pekerjaan yang sulit bisa menjadi mudah apabila pelaksanaan pendampingan berjalan dengan baik, 3) mempererat tali persaudaraan dan silaturrahmi antara guru dengan kepala sekolah, dan antar guru sejawat, 4) proses pembelajaran mengikuti skenario yang telah direncanakan pada Rencana Pelaksanaan Pembelajaran Harian (RPPH). Dengan memperhatikan keunggulan dimaksud peneliti melaksanakan pendampingan dalam penyusunan RPPH bagi guru binaannya dan pada gilirannya akan melahirkan guru yang profesional melalui penyusunan RPPH yang sesuai dengan harapan.

Rendahnya kompetensi guru TK PGRI 4 Mataram dalam penyusunan Rencana Pelaksanaan Pembelajaran Harian (RPPH) diupayakan pembimbingan/pendampingan secara klasikal dan individual. Untuk membuktikan keunggulan Pelaksanaan Pendampingan maka diadakan Penelitian Tindakan Sekolah (PTS) dengan judul: "Upaya Meningkatkan Kompetensi guru TK PGRI 4 Mataram Semester Satu Tahun Pelajaran 2018/2019 melalui Pendampingan".

\section{Rumusan Masalah}

"Bagaimana pelaksanaan pendampingan upaya meningkatkan kompetensi guru dalam penyusunan Rencana Pelaksanaan Pembelajaran Harian (RPPH) bagi guru TK PGRI 4 Mataram semester Satu Tahun Pelajaran 2018/2019?"

\section{Tujuan Penelitian}

"Untuk mengetahui efektifitas pelaksanaan pendampingan secara klasikal dan individual berbasis KKG dalam upaya meningkatkan kompetensi guru dalam penyusunan RPPH semester satu tahun pelajaran 2018/2019 di TK PGRI 4 Mataram."

\section{Manfaat Penelitian}

1. Bagi Kepala TK PGRI 4 Mataram; bermanfaat dalam upaya meningkatkan kompetensi guru dalam penyusunan RPPH, melalui kegiatan pendampingan.

2. Bagi guru TK PGRI 4 Mataram; bermanfaat dalam upaya penyusunan RPPH yang baik dan benar, sehingga dapat diterapkan secara optimal dan terstruktur dalam proses pembelajaran di kelas senyatanya sesuai dengan situasi dan kondisi kelas yang menjadi tanggung jawabnya.

\section{KAJIAN PUSTAKA \\ Kerangka Teoritis \\ Kompetensi Guru}

Dalam Undang-Undang RI No. 14

Tahun 2005 tentang Guru dan Dosen menjelaskan bahwa "Kompetensi adalah 
seperangkat pengetahuan, keterampilan, dan perilaku yang harus dimiliki, dihayati, dan dikuasai oleh guru atau dosen dalam melaksanakan tugas keprofesionalan". Menurut Uzer Usman (2001: 14) "Kompetensi guru adalah kemampuan seorang guru dalam melaksanakan kewajiban-kewajibannya secara bertanggung jawab dan layak".

Tugas guru dalam menjalankan profesi kependidikannya yang teramat luas, termasuk di dalamnya tugas guru sebagai pendidik dan sebagai pengajar. Akan tetapi, muara tugas utama kedua peran tersebut terjadi pada arena proses pembelajaran, yaitu suatu upaya guru dalam menciptakan situasi interaksi pergaulan sosial dengan merekayasa lingkungan yang kondusif bagi terjadinya perkembangan optimal peserta didik. Guru memainkan multiperan dalam proses pembelajaran yang diselenggarakan dengan tugas yang amat bervariasi. Salah satu tugas utama guru adalah mengajar. Guru akan memiliki kompetensi mengajar apabila memiliki pemahaman dan penerapan secara teknis berbagai metode pembelajaran. Kompetensi guru rnerupakan perpaduan antara kemampuan personal, keilmuan, teknologi, sosial, dan spiritual yang secara menyeluruh membentuk kompetensi standar profesi guru, yang mencakup penguasaan materi, pemahaman terhadap peserta didik, pembelajaran yang mendidik, pengembangan pribadi dan profesionalisme

Yang dimaksud dengan kompetensi guru dalam penelitian tindakan sekolah (PTS) ini adalah kemampuan 4 (empat) guru sasaran dalam penyusunan Rencana Pelaksanaan Pembelajaran Harian (RPPH). Adapaun ciri-ciri RPPH dikatakan baik dan benar adalah: 1) memuat aktifitas proses belajar mengajar yang akan dilaksanakan oleh guru dan menjadi pengalaman belajar bagi peserta didik, 2) langkah-langkah pembelajaran disusun secara sistematis agar tujuan pembelajaran dapat dicapai, 3) langkah-langkah pembelajaran disusun serinci mungkin, sehingga apabila RPP digandakan guru lain (misalnya, ketiga guru mata pelajaran tidak hadir) mudah dipahami dan tidak menimbulkan penafsiran ganda.

\section{Rencana Pelaksanaan Pembelajaran Harian (RPPH)}

Rencana pelaksanaan pembelajaran adalah program perencanaan pelaksaan pembelajaran harian yang akan di laksanakan oleh pendidik kepada peserta didik sesuai komponen - komponen yang telah ditetapkan. Bagian dari komponen RPPH meliputi identitas program, materi, alat dan bahan, kegiatan pembuka, kegiatan inti, kegiatan penutup dan rencana penilaian.

Sebagai guru RPPH dapat dikatakan sebagai pedoman dalam melakukan proses belajar mengajar. Karena dengan adanya rencana pelaksanaan pembelajaran ( RPPH ) seorang guru dapat melaksanakan proses belajar mengajar dengan baik dan berkesinambungan dengan hasil penilaian yang optimal untuk membangun sikap pengetahuan dan sikap ketampilan yang dimiliki oleh peserta didik.

Dalam menyusun RPPH sebaiknya memperhatikan KI dan KD sesuai golongan umur peserta didik selanjutnya memuali tahapan seperti yang ada di bawah ini :

1. Menulis Identitas Program

a. Semester/bulan minggu

b. Hati/Tanggal

c. Tema

d. Kelompok sasaran

e. Kompetensi Dasar

2. Materi RPPH

a. materi diambil dari materi yang telah dijabarkan pada RPPM

b. Materi Sejalan sesaui dengan materi yang sebelumnya

3. Alat dan Bahan

alat dan Bahan dipersiapkan sesuai dengan materi yang akan di ajarkan pada saat itu dan dapat di pilih sesuai dengan minat perkembangan peserta didik.

4. Kegiatan Pembukaan

Kegiatan Pembukaan sangat penting dalam menyusun RPPH yang berjuan untuk membantu minat peserta didik dalam melakukan aktifitas pembelajaran yang akan 
dilaksanakan. Kegiatan Pembukaan sangat penting untuk mengenalkan pembelajaran yang akan di lakukan pada kegiatan inti. Pada bagian ini guru akan menjelaskan dan mengenalkan materi ajar yang akan di lakukan oleh peserta didik.

5. Kegiatan Inti

Pada kegiatan inti guru akan melakukan kegiatan pembelajaran dengan pendekatan saintifik yaitu peserta didik mengamati, menanya, mengumpulkan informasi, menalar kemudian mengkomunikasikan.

6. Kegian penutup.

Kegiatan Penutup dilakukan pada akir kegiaatan proses belajar mengajar, yang mengingatkan kegiatan pembuka, kegiatan penutup dan di akhiri dengan berdoa.

7. Penilaian

Rencana Penilaian memuat Indikator perkembangan dan pengumpulan data yang akan di gunakan. Indikator yang di gunakan sesuai materi pembelajaran dan proses pembelajaran.

\section{Pendampingan}

Pendampingan adalah Upaya terus menerus dan sistematis dalam mendampingi (menfasilitasi) individu, kelompok maupun komunitas dalam mengatasi permasalahan dan menyesuaikan diri dengan kesulitan hidup yang dialami sehingga mereka dapat mengatasi permasalahan tersebut dan mencapai perubahan hidup ke arah yang lebih baik. (Yayasan Pulih, 2011). Pendampingan merupakan proses interaksi timbal balik (tidak satu arah) antara individu/ kelompok/komunitas yang mendampingi dan individu/kelompok/komunitas yang didampingi yang bertujuan memotivasi dan mengorganisir individu/kelompok/komunitas dalam mengembangkan sumber daya dan potensi orang yang didampingi dan tidak menimbulkan ketergantungan terhadap orang yang mendampingi (mendorong kemandirian). (Yayasan Pulih, 2011). Pendampingan dapat dilakukan dalam berbagai bentuk maupun situasi dengan pendekatan yang beragam baik formal maupun non formal, individu, kelompok maupun komunitas.

Dikalangan dunia pengembangan masyarakat istilah "pendampingan" merupakan istilah baru yang muncul sekitar 90-an, sebelum itu istilah yang banyak dipakai adalah "pembinaan". Ketika istilah pembinaan ini dipakai terkesan ada tingkatan yaitu ada Pembinaan dan yang dibina, pembinaan adalah orang atau lembaga yang melakukan pembinan sedangkan yang dibina adalah masyarakat. Kesan lain yang muncul adalah pembinaan sebagai pihak yang aktif sedang yang dibina pasif atau pembinaan adalah sebagi subjek yang dibina adalah objek. Oleh karena itu istilah pendampingan dimunculkan, langsung mendapat sambutan positif dikalangan praktisi Pengembangan Masyarakat. Karena kata pendampingan menunjukan kesejajaran (tidak ada yang satu lebih dari yang lain), yang aktif justru yang didampingi sekaligus sebagai subjek utamanya, sedang pendamping lebih bersifat membantu saja. Dengan demikian pendampingan dapat diartikan sebagai satu interaksi yang terus menerus antara pendamping dengan anggota kelompok atau masyarakat hingga terjadinya proses perubahan kreatif yang diprakarsai oleh anggota kelompok atau masyarakat yang sadar diri dan terdidik ( tidak berarti punya pendidikan formal)

Yang dimaksud dengan pendampingan dalam penelitian tindakan sekolah (PTS) ini adalah kepala TK PGRI 4 Mataram selaku peneliti membimbing/mendampingi terhadap 4 (empat) guru sasaran dalam penyusunan RPPH. Dalam pelaksanaannya pendampingan dilakukan melalui 2 (dua) tahapan. Tahap I semua guru dikumpulkan untuk mendapatkan penjelasan teknik tata cara penyusunan RPPH sesuai dengan bidang studi/mata pelajaran yang diampunya. Tahap II yaitu pendampingan individual, dimana peneliti mendampingi secara individu dalam kelompok kecil untuk menjelaskan lebih rinci tata cara menyusun RPPH. 


\section{Kelompok Kerja Guru (KKG)}

Trimo (2007: 12) Kelompok Kerja Guru yaitu suatu organisasi profesi guru yang bersifat struktural yang dibentuk oleh guru-guru di suatu wilayah atau gugus sekolah sebagai wahana untuk saling bertukaran pengalaman guna meningkatkan kemampuan guru dan memperbaiki kualitas pembelajaran.

Sedangkan Sumadji (2013: 1) menyatakan, "Kelompok kerja guru ini merupakan wadah atau tempat bagi guru untuk bermusyawarah tentang hal-hal untuk peningkatan mutu dalam pembelajaran". Pedoman Pembinaan Gugus PAUD (2012: 3) menyatakan bahwa "Kelompok Kerja Guru (KKG) PAUD merupakan program kerja gugus sebagai wahana bengkel kerja guru-guru anggota Gugus". Pendapat lain dikatakan oleh Uceh Nurabnu (2012: 24), Kelompok Kerja Guru (KKG) TK/PAUD "merupakan salah satu bagian dari program kerja gugus sebagai wahana bengkel kerja guru-guru TK/PAUD selaku anggota gugus, dan merupakan pintu masuk pertama yang paling strategis dalam program peningkatan kompetensi pendidik TK/PAUD”.

Melalui KKG guru memiliki kesempatan dan berpotensi mendiskusikan penyelesaian permasalahan yang dihadapi di kelas. Trimo (2007: 12) menyatakan, "pembinaan melalui KKG memberikan kesempatan bagi guru yang lebih luas (dimungkinkan semua guru terlibat), dibanding bentuk pembinaan yang lain (harus menunggu kesempatan)". Uceh Nurabnu (2012: 24) Gugus TK merupakan wadah kegiatan Kelompok Kerja Guru (KKG) dan Kelompok Kerja Kepala TK (KKKTK) yang telah ditetapkan melalui Direktur Jendral Pendidikan Dasar dan Menengah, Departemen Pendidikan dan Kebudayaan Nomor 086/c/Kep/v/tanggal 8 Mei 1995.

Standar pengembangan KKG Derektorat
Profesi Pendidik Direktorat Jendral
Peningkatan Mutu Pendidikan dan Tenaga
Kependidikan Departemen Pendidikan dan
Kebudayaan Republik Indonesia menyatakan bahwa KKG merupakan wadah atau forum kegiatan profesional bagi para guru Sekolah Dasar/Madrasah Ibtidaiyah di tingkat gugus atau kecamatan yang terdiri dari beberapa guru dari berbagai sekolah".

Sumadji (2013) menyatakan, "Kelompok Kerja Guru (KKG) bertujuan untuk menjadikan guru lebih profesional dalam upaya peningkatan mutu pendidikan". Melalui pendekatan sistem pembinaan profesional diharapkan guru mampu merencanakan, melaksanakan, dan mengevaluasi kegiatan pembelajaran. Muhtadi (2008: 13) menyatakan, "Pembentukan KKG bertujuan untuk memfasilitasi kegiatan yang dilakukan di pusat kegiatan guru berdasarkan masalah dan kesulitan yang dihadapi guru, kemudian memberikan bantuan profesional kepada guru kelas dan mata pelajaran di sekolah, serta meningkatkan pemahaman, keilmuan, keterampilan dan pengembangan sikap profesional berdasarkan kekeluargaan dan saling mengisi (sharing)".

Direktorat Pembinaan TK dan SD, Sriwasono (2010: 2) menyatakan, "tujuan umum mengembangkan kegiatan KKG untuk meningkatkan mutu pembelajaran sesuai dengan standar pelayanan pendidikan dalam kerangka penjaminan mutu pendidikan nasional".

Yang dimaksud dengan kelompok kerja guru (KKG) dalam penelitian ini adalah 4 (empat) guru TK PGRI 4 Mataram yang menjadi sasaran dalam pelaksanaan pendampingan dalam penyusunan RPPH. Kegiatan nyata KKG TK PGRI 4 Mataram yaitu penysunan Rencana Pelaksanaan Pembelajaran Harian (RPPH) yang dibimbing langsung oleh kepala sekolah selaku peneliti. Dalam kegiatan ini semua guru kelas dari kelas A dan kelas B menyusun RPPH secara individual dalam forum KKG. Kendala/kesulitan yang dialami oleh guru langsung diberikan bimbingan, perbaikan, dan penyempurnaansesuai dengan situasi dan kondisi pada saat KKG yang diselenggarakan di TK PGRI 4 Mataram. 


\section{Kerangka Konseptual}

Variabel harapan dalam penilaian ini adalah meningkatnya kompetensi 4 (empat) guru sasaran dalam penyusunan RPPH, sedangkan variabel tindakan dalam penelitian iniadalah melaksanakan pendampingan secara klasikal (kelompok besar) dan pendampingan individual (kelompok kecil/perorangan) berbasis KKG.

\section{Hipotesis Tindakan}

“ jika pendampingan dilaksanakan dengan baik, maka kompetensi guru dalam penyusunan RPPH bagi guru sasaran TK PGRI 4 Mataram semester satu tahun pelajaran 2018/2019 dapat di tingkatkan"

\section{METODE PENELITIAN}

\section{Jenis Tindakan}

\section{Setting Penelitian}

Penelitian Tindakan Sekolah (PTS) ini dilaksanakan di TK PGRI 4 Mataram yang pelaksanaannya melalui kegiatan pendampingan berbasis KKG bagi 4 (empat) guru sasaran dalam penyusunan RPPH yang dilaksanakan dalam forum KKG sekolah

\section{Jenis Tindakan dan Dampak yang diharapkan}

- Jenis Tindakan : pendampingan berbasis $\mathrm{KKG}$ dalam penyusunan RPPH bagi 4 (empat) guru sasaran di TK PGRI 4 Mataram semester satu tahun pelajaran 2018/2019

- Dampak yang diharapkan :

Meningkatnya kompetensi 4 (empat) guru sasaran dalam penyusunan $\mathrm{RPPH}$.

\section{Perencanaan Tindakan}

\section{Jenis tindakan yang dilakukan}

1. Kepala sekolah menginformasikan hasil pantauan, supervisi administrasi terhadap 4 (empat) guru sasaran bahwa guru-guru dimaksud masih belum mampu/mengalami kendala/hambatan-hambatan dalam penyusunan RPPH.

2. Kepala sekolah menyampaikan perlunya diadakan pendampingan berbasis KKG bagi guru sasaran dalam penyusunan RPPH
3. Kepala Sekolah menyampaikan materi pendampingan sesuai dengan skenario pelaksanaan pendampingan berbasis $\mathrm{KKG}$ yang dirinci sebagai berikut:

- Pendampingan klasikal. Pada kegiatan ini peneliti menyampaikan materi secara klasikal dilanjutkan dengan kegiatan kerja kelompok (diskusi kelompok)

- Pendampingan individual. Pada kegiatan ini peneliti mengamati kegiatan kelompok dan mendampingi secara individual terutama bagi peserta pendampingan yang mengalami kesulitan.

Untuk mendapatkan gambaran riil tentang skenario pelaksanaan tindakan pada kegiatan pendampingan berbasis KKG ini dapat di gambarkan sebagai berikut:

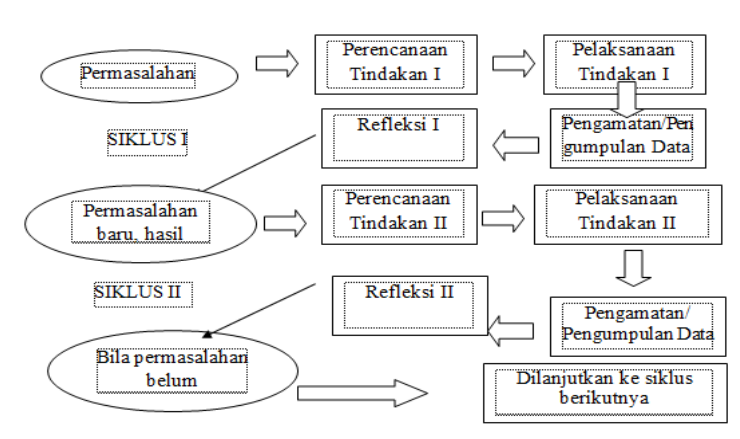

(Suharjono, 2009)

Gambar 3.1. : Skenario Tindakan

\section{Pelaksanaan Tindakan}

Pelaksanaan tindakan yang meliputi deskripsi tindakan yang dilakukan meliputi pelaksanaan rencana tindakan yang telah disiapkan, termasuk didalamnya langkahlangkah pelaksanaan atau praktik kepengawaasan di sekolah dalam setiap siklus (Suharjono, 2009). Dalam kegiatan ini peneliti melakukan kegiatan pendampingan penyusunan Rencana Pelaksanaan Pembelajaran Harian (RPPH) dengan berpedoman pada perencanaan pendampingan yang telah di tetapkan.

\section{Evaluasi dan Refleksi Tindakan}

Pada tahapan ini peneliti melakukan kajian dan penelitian proses tindakan dan hasil atau dampak tindakan terhadap perubahan 
perilaku sasaran (nana Sujana, 2009:39). Adapun kegiatan riilnya adalah: 1) membandingkan hasil pengamatan pelaksanaan kerja kelompok/diskusi yang difokuskan kegiatan penyusunan RPPH, 2) membandingkan hasil kerja individual dari 4 (empat) guru sasaran dalam penyusunan RPP dengan indikator keberhasilan yang telah ditetapkan.

\section{Siklus Tindakan}

Dalam penelitian ini di rencanakan sebanyak 2 (duaa) siklus, masing-masing siklus 1 (satu) kali pertemuan dengan agenda 2 (dua) kegiatan secara terpadu yaitu pendampingan klasikal/kelompok besar dan pendampingan individual/kelompok kecil. Kegiatan masingmasing siklus terdiri dari 4 (empat) tahapan yaitu perencanaan, pelaksanaan, observasi, dan refleksi. Untuk mendapatkan gambaran secara rinci kegiatan masing-masing tahapan dapat di jelaskan sebagai berikut:

\section{SIKLUS I}

\section{Tahap I : Perencanaan Tindakan}

1.1. Menyusun materi pendampingan

1.2. Menetapkan scenario dan langkahlangkah pendampingan yang tertuang dalam Rencana Pelaksanaan pendampingan (RPP)

1.3. Menyusun instrument observasi kepala sekolah dan observasi guru
1.4. Menentukan jadwal kegiatan pendampingan

1.5. Menyusun pedoman analisa data hasil observasi dan tugas individu.

\section{Tahap II. Pelaksanaan Tindakan}

Pada tahapan ini peneliti melaksanakan kegiatan pendampingan yang dibagi menjadi 2 (dua) kegiatan penting yakni kerja kelompok dan kerja individual.

Pada kegiatan pendampingan secara berkelompok yang kegiatannya adalah :

2.1. Menyampaikan materi tentang tata cara penyusunan RPPH.

2.2. Melaksanakan diskusi kelompok kecil dalam penyusunan RPPH.

2.3. Memberikan bimbingan secara berkelompok/perorangan.

\subsection{Memberikan solusi terhadap permasalahan yang dihadapi oleh guru}

2.5. Memberikan penguatan/reward

2.6. Memberikan tugas individual.

Pada kegiatan pendampingan individual yang dilakukan secara bergiliran, dengan cara peneliti mendekati guru satu persatu dalam kelompok untuk membimbing secara individual agar permasalahan-ppermasalahan dapat dipecahkan dengan baik dan benar.

\section{Tahap III. Observasi/pengumpulan Data}

3.1. Pengamatan terhadap aktifitas guru peserta pendampingan

3.2. Pengamatan terhadap kinerja guru dalam penyusunan RPPH.

3.3. Menilai hasil kerja guru secara individual

Tahap IV. Refleksi

4.1. Renungan atas data hasil observasi dan hasil kerja secara individual.

4.2. Pengolahan data hasil penelitian dan mencocokkan dengan indikator keberhasilan.

4.3. Rencana perbaikan dan penyempurnaan

4.4. Memberikan penguatan atas hasil yang diperolehnya.

4.5. Rencana tindak lanjut.

\section{SIKLUS II}

Jenis kegiatan pada siklus II ini pada dasarnya sama dengan siklus I, bedanya hanya terjadi perbaikan/penyempurnaan dalam pelaksanaannya.

\section{Indikator Keberhasilan}

1. Hasil observasi kepala sekolah maupun observasi guru peserta pendampingan telah mencapai skor rata-rata $\geq 4,0$ (Kategori baik).

2. Hasil kerja secara individual penyusunan RPPH berdasarkan kurikulum 2007 dinyatakan telah berhasil jika mencapai $\geq$ $85 \%$ dengan nilai rata-rata $\geq 80,00$ (Kategori Baik).

\section{HASIL DAN PEMBAHASAN}

\section{Laporan Hasil}

Deskripsi Siklus I

Tahap Perencanaan

Pada tahapan ini peneliti melakukan: 1) menyusun materi pendampingan, 2) 
menetapkan skenario dan langkah-langkah pendampingan yang tertuang dalam Rencana Pelaksanaan Pendampingan (RPP), 3) menyusun instrumen observasi kepala sekolah dan instrumen observasi guru, 4) menentukan jadwal kegiatan pendampingan, 5) menyusun pedoman analisis data

\section{Tahap Pelaksanaan}

Pada tahapan ini peneliti melakukan pendampingan secara klasikal maupun pendampingan secara individual, dengan rincian kegiatan sebagai berikut:

- Pendampingan klasikal/kelompok; 1) menyampaikan materi tentang tata cara penyusunan RPPH, 2) melaksanakan diskusi kelompok kecil dalam penyusunan RPP, 3) memberikan bimbingan secara berkelompok, 4) memberikan solusi terhadap permasalahan yang dihadapi oleh guru, 5) memberikan penguatan/reward, dan 6) memberikan tugas individual.

- Pendampingan individual, jenis kegiatannya adalah; 1) pada saat guru bekerja dalam kelompok/diskusi kelompok peneliti membimbing guru yang mengalami kesulitan dalam penyusunan RPP secara kelompok kecil/perorangan, 2) memberikan solusi/pemecahan terhadap kesulitan yang dirasakan secara individual, 3) kegiatan seterusnya sampai ke 4 (empat) guru peserta pendampingan mendapatkan giliran pendampingan secara individual

\section{Tahap Observasi}

Observasi kepala sekolah memperoleh skor rata-rata sebesar $(3,20)$, observasi guru memperoleh skor rata-rata sebesar $(3,50)$ dan nilai rata-rata pendampingan individual sebesar (70,98).

\section{Tahap Refleksi}

Pada tahapan ini peneliti merenung atas perolehan data hasil observasi kepala sekolah, observasi guru, dan nilai individual hasil penyusunan RPPH. Selanjutnya peneliti mengolah data dan hasilnya di cocokkan dengan indikator keberhasilan.

Karena perolehan hasil masih dibawah indikator keberhasilan yang direncanakan, maka pada siklus berikutnya akan diadakan perbaikan dan penyempurnaan dari serangkaian kegiatan pendampingan secara klasikal maupun secara individual, namun demikian peneliti tetap memberikan penguatan atas hasil yang diperolehnya dan penelitian dilanjutkan pada siklus II dengan mengoptimalkan semua jenis tindakan dalam pendampingan sehingga di peroleh hasil yang memuaskan.

\section{Deskripsi Siklus II \\ Tahap Perencanaan}

Tahapan perencanaan pada siklus II jenis kegiatannya masih sama dengan siklus I, bedanya pada siklus II ini lebih memfokuskan perbaikan/penyempurnaan dalam proses pendampingan klasikal maupun pendampingan individual, yang jenis kegiatannya adalah: 1) menyempurnakan materi pendampingan, 2) menetapkan skenario pendampingan, 3) menetapkan instrumen observasi kepala sekolah maupun observasi guru, 4) menetapkan jadwal kegiatan pendampingan, 5) menyusun pedoman analisis data hasil observasi dan tugaas individu

\section{Tahap Pelaksanaan}

- Pendampingan klasikal/kelompok; 1) menyampaikan/merefleksi hasil perolehan data pada siklus I, 2) menjelaskan ulang tata cara penyusunan RPPH secara lebih rinci, 3) perbaikan RPPH secara berkelompok/diskusi kelompok, 4) memberikan refleksi terhadap hasil kerja kelompok yang mengalami kendala, 5) memberikan penghargaan/reward dan 6) memberikan tugas individual.

- Pendampingan individual/kelompok kecil; 1) pada saat proses kerjasama dalam kelompok, peneliti mengamati/mencermati hasil kerja secara individual, 2) memberikan bimbingan/merefleksi terhadap hasil kerja individual yang masih mengalami kendala, 3) begitu seterusnya sampai semua guru peserta pendampingan mendapatkan pendampingan secara individual.

\section{Tahap Observasi/Pengumpulan Data}

Observasi kepala sekolah memperoleh skor rata-rata sebesar $(4,50)$, observasi guru memperoleh skor rata-rata sebesar (450) dan 
nilai rata-rata pendampingan individual sebesar $(89,82)$.

\section{Tahap Refleksi}

Pada tahapan ini peneliti merenung atas perolehan data hasil observasi kepala sekolah, observasi guru, dan nilai individual hasil penyusunan RPPH. Kemudian di olah engan menggunakan rumus yang telah ditetapkan.

Karena perolehan hasil siklus II sudah melebihi indikator keberhasilan, maka tidak perlu ada perbaikan/penyempurnaan dalam penyusunan RPPH, selanjutnya peneliti memberikan penghargaan/reward kepada semua guru peserta pendampingan karena dari 4 (empat) guru sasaran 100\% sudah memperoleh nilai rata-rata $\geq 80,00$. Penelitian dinayatakan berhasil dan tindakan dihentikan pada siklus II.

\section{Pembahasan}

\section{SIKLUS I}

\section{Tahap Perencanaan}

Dalam penyusunan materi pendampingan, menetapkan skenario dan langkah-langkah pendampingan, penyusunan instrumen observasi kepala sekolah dan instrumen observasi guru mengalami kendala, tetapi setelah meminta bimbingan dan petunjuk dari pembimbing, kendala yang dihadapi dapat diatasi dan diselesaikan dengan baik.

\section{Tahap Pelaksanaan}

Kegiatan nyata dalam pelaksanaan pendampingan dapat dijabarkan sebagai berikut: pada saat menyampaikan materi tentang tata cara penyusunan RPPH mengalami kendala yang disebabkan peneliti masih kekurangan sumber/buku literatur, sehingga berdampak tertundanya dalam penyusunan, solusi yang dilakukan peneliti mencari beberapa buku literatur terkait dengan tata cara penyusunan RPP termasuk mencari di internet, akhirnya materi pendampingan dapat tersusun dengan baik. Dalam pelaksanaan bimbingan pada saat peserta pendampingan melakukan diskusi/kerjasama dalam kelompok, peneliti berkeliling memberikan bimbingan dan solusi terhadap peserta yang mengalami kesulitan. Pada kegiatan ini peneliti tidak mengalami hambatan/permasalahan artinya berjalan sesuai dengan rencana.

\section{Tahap Observasi/Pengumpulan Data}

Hasil perolehan skor/nilai selama pendampingan pada siklus I peneliti memperoleh skor rata-rata $(3,20)$ dari indikator keberhasilan yang direncanakan yaitu $\geq 4,0$. Perolehan skor rata-rata aktifitas peserta pendampingan pada siklus I yaitu $(3,50)$. Perolehan nilai rata-rata hasil kerja guru dalam penyusunan RPPH secara individual memperoleh rata-rata $(70,98)$ dari indikator keberhasilan $\geq 80,0$ (kategori baik).

\section{Tahap Refleksi}

Perolehan skor rata-rata hasil observasi kepala sekolah selama proses pendampingan baru memperoleh skor rata-rata $(3,20)$, sementara perolehan hasil observasi peserta pendampingan sebagai aktifitas peserta selama pendampingan baru memperoleh skor rata-rata $(3,50)$, dan nilai rata-rata hasil penyusunan RPPH baru mencapai nilai rata-rata $(70,98)$. Dari perolehan hasil dimaksud peneliti merenung mencari faktor kendala dan penyebab sehingga hasil masil belum optimal. Dari hasil renungan itu akhirnya peneliti menemukan solusi untuk dapat dilaksanakan pada kegiatan pendampingan siklus berikutnya.

\section{SIKLUS II}

\section{Tahap Perencanaan}

Kesalahan-kesalahan yang terjadi pada siklus I sudah diperbaiki pada siklus II, sehingga pada tahapan ini peneliti bisa melakukan dengan baik. Kegiatan pada tahap perencanaan ini meliputi; 1) penyempurnaan penyusunan materi pendampingan, 2) perbaikan skenario/strategi/langkah-langkah

pendampingan yang mengarah kepada peserta aktif, 3) menetapkan instrumen observasi kepala sekolah dan instrumen observasi guru, 4) menentukan jadwal kegiatan dan menetapkan pedoman analisa data hasil observasi dan hasil kerja individual.

\section{Tahap Pelaksanaan}

Pada tahapan ini, peneliti terlebih dahulu melakukan refleksi atas capaian hasil yang diperoleh pada siklus I. Kendala-kendala 
dan permasalahan yang terjadi dibahas sampai semua peserta pendampingan memahami dan menyadari akan kekurangan, kesalahan dan halhal yang bersifat krusial dapat dipecahkan pada saat kegiatan refleksi.

Kegiatan selanjutnya peneliti menyampaikan materi pendampingan secara perlahan-lahan, ringkas dan jelas sehingga peserta pendampingan lebih paham dan mengerti tata cara penyusunan RPPH. Pelaksanaan diskusi kelompok dioptimalkan.

\section{Tahap Observasi}

Pada siklus II perolehan skor rata-rata hasil observasi kepala sekolah adalah $(4,50)$ dari indikator keberhasilan $\geq 4,00$, ini artinya menunjukkan peningkatan yang sangat signifikan bila dibandingkan dengan perolehan hasil pada siklus I. Skor rata-rata hasil observasi guru yaitu aktifitas selama pendampingan dalam forum KKG memperoleh skor rata-rata $(4,50)$ dari indikator keberhasilan $\geq 4,00$. Dari hasil ini nampak nyata bahwa aktifitas peserta pendampingan pada siklus II mengalami peningkatan yang sangat tajam karena sudah mampu melampaui indikator keberhasilan yang telah ditetapkan. Nilai ratarata hasil kerja individual dalam penyusunan RPPH yakni $(89,82)$ dari indikator keberhasilan $(\geq 80,00)$.

\section{a. Tahap Refleksi}

Berdasarkan hasil akhir perolehan skor rata-rata observasi kepala sekolah dan observasi guru serta hasil kerja individual penyusunan RPPH semuanya telah melampaui indikator keberhasilan maka dapat disimpulkan bahwa: 1) upaya untuk menyempurnakan materi pendampingan dinyatakan berhasil, 2) pelaksanaan untuk memperbaiki strategi penyampaian materi tata cara penyusunan RPP dan strategi pendampingan telah mampu meningkatkan motivasi dan kinerja guru sehingga perolehan hasil yang diharapkan dapat tercapai, 3) upaya untuk mengoptimalkan pelaksanaan pendampingan individual telah membawa dampak positif terhadap perolehan hasil dalam penyusunan RPPH.

Jurnal Ilmu Sosial dan Pendidikan
Karena semua indikator keberhasilan telah tercapai maka penelitian tindakan sekolah dihentikan pada siklus II dan dinyatakan berhasil memotivasi guru untuk lebih bergairah dan lebih bersemangat dalam upaya penyusunan RPPH. Penelitian Tindakan Sekolah dengan judul "Upaya Meningkatkan Kompetensi Guru Kelas Dalam Penyusunan Rencana Pelaksanaan Pembelajaran Harian (RPPH) Guru TK PGRI 4 Mataram Semester Satu Tahun pelajaran 2018/2019 Melalui

\section{Kesimpulan}

Perolehan data selama penelitian dapat dipaparkan sebagai berikut:

\begin{tabular}{|c|c|c|c|c|c|}
\hline \multirow{2}{*}{$\mathrm{N} 0$} & \multirow{2}{*}{ Jenis Kegiatan } & \multirow{2}{*}{$\begin{array}{l}\text { Indikator } \\
\text { Keberihasilan }\end{array}$} & \multicolumn{2}{|c|}{ Peroleban } & \multirow{2}{*}{ Ket } \\
\hline & & & Siklus I & Siklus II & \\
\hline 1 & Hasil Observasi Kepala Sekolah & $\geq 4,00$ & 3,20 & 4,50 & Tuntas \\
\hline 2. & Hasil Observasis Guru & 24,00 & 3,50 & 4,50 & Tuntas \\
\hline 3. & Hasil Kerja Individual & 380,00 & 70,98 & 89,82 & Tuntas \\
\hline
\end{tabular}

Pelaksanaan pendampingan berbasis KKG sangat efektif untuk meningkatkan kompetensi guru dalam penyusunan RPPH bagi guru sasaran 4 (empat) guru TK PGRI 4 Mataram dalam penyusunan RPPH. Hal ini dibuktikan meningkatnya perolehan hasil observasi dan hasil kerja individual dari siklus I ke siklus II. Penelitian tindakan sekolah (PTS) ini dinyatakan berhasil dan dihentikan pada siklus II.

\section{Saran}

Disarankan kepada rekan kepala sekolah lain untuk melakukan pendampingan dengan semua guru mata pelajaran dibawah binaan pada sekolah masing-masing dalam upaya meningkatkan kompetensinya khususnya dalam penyusunan RPPH yang bisa diterapkan dalam proses pembelajaran di kelas senyatanya. Dampak yang diharapkan yaitu meningkatnya kualitas/mutu peserta didik di sekolah binaan melalui proses pembelajaran yang dilandasi dengan penyusunan RPPH.

Kepada seluruh guru TK PGRI 4 Mataram disarankan untuk membiasakan melakukan musyawarah bersama dalam forum KKG mata pelajaran yang diampunya, khususnya dalam penyusunan RPPH, sehingga 
berdampak meningkatnya kompetensi guru dalam proses pembelajaran di kelas senyatanya dan pada gilirannya prestasi belajar peserta didik dapat ditingkatkan.

\section{DAFTAR PUSTAKA}

Anonim, 2018, Definisi Pendampingan, dalam https://kamuspsikososial.wordpress.com /tag/definisi-pendampingan/, diakses tanggal 13 Juli 2018 Pukul 10.45 Wita

Anonim, 2018, Pengertian Pendampingan, dalam http://www.bintans.web.id/2010/12/pengertianpendampingan.html, diakses tanggal 13 Juli 2018 Pukul 11.04 Wita

Budi Wahyono, 2018, Kompetensi Guru, dalam http://www.pendidikanekonomi.com/201 3/03/pengertian-kompetensi-guru.html, diakses tanggal 14 Juli 2018 Pukul 11.00 wita

Anonim, 2018, Pengertian Kompetensi dan Kompetensi Guru, dalam http://penagurusd.blogspot.com/2017/12/pengertianrpph-paud-kurikulum-2013.html , di akses 14 Juli 2018 Pukul 11.26 wita

Irwan sahaja , 2018, Pengertian Kelompok Kerja Guru, dalam http://irwansahaja.blogspot.co.id/2014/ 08/pengertian-kelompok-kerja-gurukkg.html, diakses tanggal 14 Juli 2018, pukul 20.30 Wita

Kementrian Pendidikan Nasional, 2010, Kepemimpinan Pembelajaran, Dirjen PMPTK

Keputusan Mentri Pendidikan Nasional No. 16 Tahun 2007, Standar Kualifikasi Akademik dan Kompetensi Guru.

Nana Sujana, 2009, Pendidikan Tingkat KePenelitian Konsep Dan Aplikasinya Bagi Peneliti Sekolah, Jakarta: LPP Bina Mitra.

Purnadi Pungki, M.W., 2009, KompetensiFaktor Kunci Keberhasilan, dalam http://vibizconsulting.com. Diakses tanggal 16 Agustus 2016 pukul 19.35 wita
Peraturan Pemerintah No. 19 tahun 2005 tentang Standar Nasional Pendidikan

Suharjono, 2009, Melaksanakan Sekolah Sebagai Kegiatan Penelitian Tindakan Sekolah Sebagai Kegiatan Pengembangan Profesi Penelitia Sekolah, Jakarta: Bumi Aksara.

Suharjono, 2012, Publikasi Ilmiah Dalam Kegiatan Pengembangan Keprofesian Berkelanjutan Bagi Guru, Jakarta: Cakrawala Indonesia.

Undang-Undang Republik Indonesia, No. 14 Tahun 2005 , Guru dan Dosen Daftar Pustaka

Winsolu, 2009, Pengertian Kompetensi, dalam http://my.opera.com/winsolu/blog/penge rtian-kompetensi Diakses tanggal 16 Agustus 2016 pukul 19.55 wita 